\title{
PARAMETERS OPTIMIZATION OF PID CONTROLLERS FOR LEATHER MANUFACTURING PROCESS BY USING GENETIC ALGORITHMS
}

\section{OPTIMIZAREA PARAMETRILOR REGULATOARELOR PID PENTRU PROCESUL DE FABRICARE A PIELII UTILIZÂND ALGORITMI GENETICI}

\author{
Adrian-Bogdan HANCHEVICI ${ }^{1,2^{*}}$, Sergiu-Adrian GUTĂ ${ }^{1}$ \\ ${ }^{1}$ INCDTP - Division Leather and Footwear Research Institute, Bucharest, Romania, email: guta.sergiu@icpi.ro \\ "Politehnica” University of Bucharest, Faculty of Automatic Control and Computers, Romania, email: adrian.hanchevici@upb.ro
}

\begin{abstract}
PARAMETERS OPTIMIZATION OF PID CONTROLLERS FOR LEATHER MANUFACTURING PROCESS BY USING GENETIC ALGORITHMS
ABSTRACT. In this paper is proposed a control strategy for leather manufacturing process. This control strategy makes use of conventional PID control algorithms in combination with an evolutionary optimization technique, namely genetic algorithms. In order to find the parameters for the PID controllers, different performance indexes are provided to the genetic algorithms. In this study the proposed control strategy is used to control one process parameter, namely the $\mathrm{pH}$ value. Simulation results are presented. The results show performance improvement which proves that the proposed control strategy is able to make the closed-loop system behave as expected according to different given performance indexes.

KEY WORDS: PID, genetic algorithms, leather manufacturing process
\end{abstract}

OPTIMIZAREA PARAMETRILOR REGULATOARELOR PID PENTRU PROCESUL DE FABRICARE A PIELII UTILIZÂND ALGORITMI GENETICI

REZUMAT. În această lucrare se propune o strategie de control pentru procesul de fabricare a pielii. Această strategie de control utilizează algoritmi de control PID convenţionali în combinaţie cu o tehnică de optimizare evolutivă, şi anume algoritmi genetici. Pentru a determina parametrii pentru regulatoarele PID, algoritmilor genetici li se acordă diferiţi indici de performanţă. În acest studiu, strategia de control propusă este utilizată pentru a controla un parametru de proces, şi anume valoarea pH-ului. Sunt prezentate rezultatele de simulare. Rezultatele arată îmbunătăţirea performanţei, ceea ce demonstrează că strategia de control propusă este capabilă să inducă sistemului în buclă închisă un comportament dorit în funcţie de diferiţii indici de performanţă stabiliţi.

CUVINTE CHEIE: PID, algoritmi genetici, procesul de fabricare a pielii

L'OPTIMISATION DES PARAMÈTRES DE CONTRÔLEURS PID POUR LE PROCÉDÉ DE FABRICATION DU CUIR EN UTILISANT DES ALGORITHMES GÉNÉTIQUES RÉSUMÉ. Cet article propose une stratégie de contrôle pour le processus de fabrication du cuir. Cette stratégie de contrôle utilise des algorithmes de contrôle PID classiques en combinaison avec la technique d'optimisation évolutive, à savoir les algorithmes génétiques. Pour déterminer les paramètres pour les contrôleurs PID, on fourni de différents indicateurs de performance aux algorithmes génétiques. Dans cette étude, la stratégie de contrôle proposée est utilisée pour contrôler un paramètre de processus, à savoir le pH. Les résultats de simulation sont présentés. Les résultats montrent une amélioration des performances, ce qui démontre que la stratégie proposée est capable de rendre le système de contrôle en boucle fermée se comporter comme prévu en fonction de divers indicateurs de performance établis.

MOTS-CLÉS: PID, algorithmes génétiques, processus de fabrication du cuir

\section{INTRODUCTION}

The PID controller is the most used and appreciated controller, being present in industrial applications for many years, proving its reliability in all this time. For SISO (single input single output) linear systems, the task of finding a suitable controller is fairly easy at the moment, given the extensive and solid grounds for PID controller design [1-3]. Given the fact that most plants are not quite linear and the controller design is made around an approximated model of the considered process, the notion and practice of tuning such controllers is widespread. When dealing with a

\section{INTRODUCERE}

Regulatorul PID este cel mai utilizat şi apreciat regulator (controler), fiind prezent în aplicaţii industriale de mulţi ani şi dovedindu-şi fiabilitatea în tot acest timp. Pentru sistemele liniare SISO (single input single output), sarcina de a găsi un regulator adecvat este destul de uşoară în acest moment, având în vedere experienţa extinsă şi solidă pentru proiectarea regulatoarelor PID [1-3]. Având în vedere faptul că cele mai multe procese nu sunt liniare şi proiectarea regulatorului se face în jurul unui model aproximativ al procesului analizat, noţiunea şi practica de ajustare a

* Correspondence to: Adrian-Bogdan HANCHEVICI, "Politehnica"University of Bucharest, Faculty of Automatic Control and Computers, Romania, email: adrian.hanchevici@upb.ro 
SISO system, the task of further tuning PID controller in closed loop is not very demanding, while in the case of MIMO (multi input multi output) systems there is the necessity of tuning more parameters. Combining this notion with the varied classes of nonlinearities and uncertainties that may occur, in one form or another, in real plants, and also taking into account that sometimes these nonlinearities and uncertainties might make computing a suitable controller nearly impossible, it stands to reason that the task of design and tuning of PID controllers for MIMO systems requires a certain degree of automation. In this paper, the focus of such design and tuning is taken over by the development, testing and validation of a heuristic algorithm that will eventually find a desired set of controllers for a MIMO system.

In [4] was presented a control strategy for leather manufacturing processes affected by variant communication delays. The control strategy is for nonlinear SISO systems, based on a multi-agent control structure with fuzzy-logic supervisor. Modeling MIMO systems has been based on approximation and linearization, as found in [5] and [6]. Control strategies for MIMO systems employed over the years include a wide range of techniques, from intelligent control, such as hybrid fuzzy-logic-neural-network control strategies [7], to adaptive control, some ensuring global stability through control schemes based on linearization [8], others resorting to multirate sampling in order to resolve the different number of inputs and outputs issue [9], or even taking on fuzzy-adaptive-based control schemes [10].

In this paper the leather manufacturing process is used as a relevant example of a MIMO non-linear system.

The paper is organized as follows. The authors start by presenting the proposed control strategy using genetic algorithms. In the next section is presented the case study. Final section contains the conclusions and the directions for future research.

\section{PROPOSED CONTROL STRATEGY}

\section{General View of the Proposed Control Strategy}

When considering the synthesis of control systems for MIMO processes, a valid approach is unor astfel de regulatoare sunt larg răspândite. Atunci când este vorba de un sistem SISO, sarcina de ajusta suplimentar regulatorul PID în buclă închisă nu necesită mult efort, în timp ce în cazul sistemelor MIMO (intrări multiple ieşiri multiple) există necesitatea de a ajusta mai mulţi parametri. Combinând această noţiune cu diferitele clase de neliniarităţi şi incertitudini care pot apărea, într-o formă sau alta, în procesele reale, şi având în vedere că uneori aceste neliniarităţi şi incertitudini ar putea face aproape imposibil calculul necesar unui regulator adecvat, este logic că sarcina de proiectare şi reglare a regulatoarelor PID pentru sistemele MIMO necesită un anumit grad de automatizare. În această lucrare, sarcina de proiectare şi reglare este preluată de dezvoltarea, testarea şi validarea unui algoritm euristic, care va găsi în cele din urmă un set dorit de regulatoare pentru un sistem MIMO.

În [4] se prezintă o strategie de control a proceselor de prelucrare a pieilor afectate de întârzierile de comunicaţii. S-a utilizat o structură de control pentru sistemele neliniare SISO bazată pe tehnologia multi-agent cu supervizare fuzzy-logic. Modelarea sistemelor MIMO se bazează pe aproximare şi liniarizare, după cum se specifică în [5] şi [6]. Strategiile de control pentru sistemele MIMO utilizate de-a lungul anilor includ o gamă largă de tehnici, de la controlul inteligent, cum ar fi strategiile hibride de control logică-fuzzy-reţea-neuronală [7], la controlul adaptiv, unele asigurând stabilitate la nivel global prin scheme de control bazate pe liniarizare [8], altele recurgând la eşantionări diferite pentru a rezolva problema numărului diferit de intrări şi ieşiri [9] sau chiar la sistemele de control fuzzy adaptive [10].

În această lucrare procesul de fabricare a pielii este folosit ca exemplu relevant al unui sistem neliniar MIMO.

Lucrarea este organizată după cum urmează. Autorii încep prin a prezenta strategia de control propusă folosind algoritmi genetici. În secţiunea următoare este prezentat studiul de caz. Seç̧iunea finală conţine concluziile şi direç̧iile de cercetare viitoare.

\section{STRATEGIA DE CONTROL PROPUSĂ}

\section{Privire generală asupra strategiei de control propuse}

Pentru a face o sinteză a sistemelor de reglare (control) pentru procesele MIMO, o abordare valabilă 
finding one or a set of controllers by means of heuristic optimization algorithms. This paper makes use of Genetic Algorithms in order to find the (sub) optimal tuning parameters for a set of conventional controllers for different parameters of a leather manufacturing process. The considered process is of MIMO (multi input - multi output) type, presenting a moderate level of complexity. The leather manufacturing process requires having the displacements on each controlled parameter. Simulation results showed that a set of manually tuned controllers for each displacement requires further tuning in order to obtain the specified performance criteria: eliminating any overshoot while trying to keep the response time relatively short. The tuning parameters are adjusted, in this paper, by means of GA optimization, while taking into account four different types of performance indexes: two general error minimization indexes, a settling time minimizing index and an overshoot eliminating index. este aceea de a găsi un regulator sau un set de regulatoare prin algoritmi de optimizare euristici. Această lucrare utilizează algoritmi genetici pentru a găsi parametrii optimi de ajustare pentru o serie de regulatoare convenţionale pentru diferiţi parametri din cadrul unui proces de fabricare a pielii. Procesul considerat este de tip MIMO (multi input - multi output) şi prezintă un nivel moderat de complexitate. Procesul de fabricare a pielii necesită reglarea fiecărui parametru. Rezultatele simulării au arătat că un set de regulatoare proiectate pentru fiecare parametru necesită o acordare suplimentară pentru a obţine criteriile de performanţă specificate: eliminarea oricărui suprareglaj, în acelaşi timp încercându-se obţinerea unui timp de răspuns relativ scurt. În această lucrare, parametrii de acord sunt optimizaţi cu ajutorul algoritmilor genetici (GA), luând în considerare patru tipuri diferite de indici de performanţă: doi indici generali de minimizare erorii, un indice de minimizare a timpului tranzitoriu şi un indice de eliminare a suprareglajului.

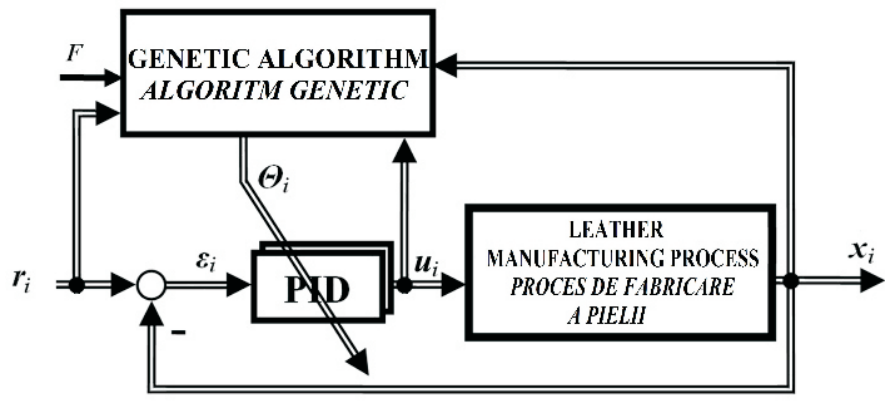

Figure 1. The proposed control strategy

Figura 1. Strategia de control propusă

The proposed control strategy makes use of a set of PID class controllers for the control of process parameters, as presented in Figure 1, where: $x_{i}$ represents the controlled displacement variables, $r_{i}$ are the setpoints, $u_{i}$ are the control signals and $\Theta_{i}$ represent the sets of tuning parameters for each PID controller employed in the system. The performance index to be minimized is $F \varepsilon\left\{I_{1}, I_{2}, I_{3}, I_{4}\right\}$. These performance indexes are discussed at the end of this section. Figure 2 presents the simulated response for one manually tuned controller.
Strategia de control propusă utilizează o serie de regulatoare de clasă PID pentru controlul parametrilor de proces, aşa cum este prezentat în Figura 1, unde: $x_{i}$ reprezintă parametrii reglaţi din cadrul procesului, $r_{i}$ sunt valorile de referinţă, $u_{i}$ sunt semnalele de comandă şi $\Theta_{i}$ reprezintă seturi de parametri de acord pentru fiecare regulator PID folosit în sistem. Indicele de performanţă care trebuie redus la minimum este $F \varepsilon\left\{I_{1}, I_{2}, I_{3}, I_{4}\right\}$. Aceşti indici de performanţă sunt discutaţi la sfârşitul acestei secţiuni. Figura 2 prezintă răspunsul simulat pentru un regulator ajustat manual. 


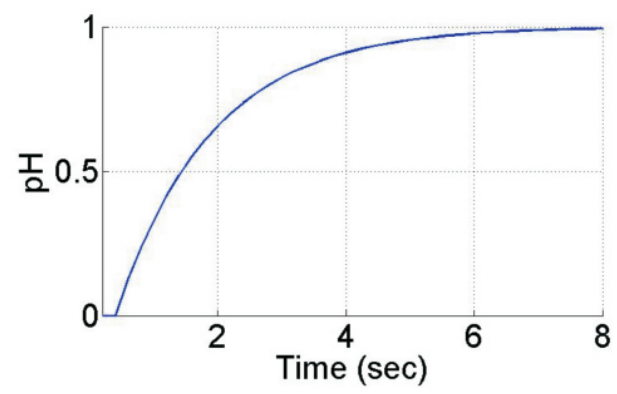

Figure 2. Simulated response

Figura 2. Răspuns simulat

The time response of each system can be considerably improved by fine-tuning the chosen PID controller. This task is a difficult one, given the interdependency of the controllers' parameters that require further adjustment.

\section{Genetic Algorithms}

Genetic algorithms (GAs) are based on a heuristic approach. As one of the most cited evolutionary optimization techniques in literature, GAs are suitable for a wide range of optimization problems, specifically those that deal with modeling uncertainties and gross approximations.

Based on the evolutionary survival-of-the-fittest concept, GAs code the problem's possible solutions into individuals. These form a population, for which an artificial evolution is performed, the advance of generations being obtained by means of natural selection.

The main steps of a GA are [11]:

- Population initialization;

- Fitness evaluation for initial population;

- While the termination condition is not met, for each generation:

- Selection of the new population;

- Recombination of individuals;

- Fitness evaluation for current population;

GAs perform searches on multiple directions in order to find the solution amongst a given population, by evaluation the fitness of each individual. The fitness is the result of an evaluation function modeling a desired objective. Its description is problem-specific, but its purpose is to eliminate unwanted solutions from the gene pool. The fitness function returns a minimization performance index which in turn will be used for the
Timpul de răspuns al fiecărui sistem poate fi îmbunătăţit considerabil prin reglajul fin al regulatorului PID ales. Această sarcină este una dificilă, având în vedere interdependenţa parametrilor regulatoarelor care necesită ajustare suplimentară.

\section{Algoritmi genetici}

Algoritmii genetici (GA) se bazează pe o abordare euristică. Fiind una dintre cele mai citate tehnici de optimizare evolutivă din literatură, GA sunt adecvaţi pentru o serie largă de probleme de optimizare, mai ales cei care se ocupă de incertitudini de modelare şi aproximăribrute.

Pe baza conceptului evolutiv de supravieţuire a celui mai adaptat, GA codifică soluţiile posibile ale problemei în indivizi. Aceştia formează o populaţie, pentru care se face o evoluţie artificială, iar generaţiile apar ca rezultat al unei selecţii naturale.

Principalele etape ale unui GA sunt [11]:

- Iniţializarea populaţiei;

- Evaluarea conformităţii populaţiei iniţiale;

- Dacă nu este îndeplinită condiţia de finalizare, pentru fiecare generaţie:

- Selecţia unei noi populaţii;

- Recombinarea indivizilor;

- Evaluarea conformităţii populaţiei actuale;

GA efectuează căutări în direcţii multiple pentru a găsi soluţia într-o populaţie dată, prin evaluarea conformităţii fiecărui individ. Conformitatea este rezultatul unei funcţii de evaluare care modelează obiectivul dorit. Descrierea acesteia este specifică problemei, dar scopul său este de a elimina soluţii nedorite dintr-un fond genetic. Funcţia de conformitate are ca rezultat un indice de performanţă de reducere la minimum care, la rândul său, va fi utilizat 
selection of the new generation. The lower the performance index, the higher the fitness of an individual (fitness $=1 /$ (performance index)), the closer it is to the solution. The performance index of the entire algorithm is given by the fitness of the best population, or, should the case be, by the fitness of the solution.

This paper tests three different selection functions for the evaluated population. The roulette wheel selection generates a roulette wheel in which each individual is represented according to its fitness, proportionally. The larger the fitness value, the more room it will have on the wheel. The selection occurs by generating a random number and counting the wheel sections. The individuals with greater fitness are more likely to be selected since they have a larger section of the roulette wheel assigned. The rank selection function makes use of a fitness-based sorted population list, from which the extremes are eliminated. The resulting population will then have greater chances to be selected. The method has a slower convergence than roulette wheel selection. The tournament selection procedure involves running several tournaments among a specified number of individuals chosen at random from the evaluated population. The winner of each tournament is considered to be the one with the best fitness value, and therefore is selected for recombination.

\section{Performance Evaluation}

By means of the GA evolutionary optimization technique, the parameters of the chosen PID controllers are fine-tuned in a simulated environment.

In [12] is presented a genetic algorithm control of a non-linear MIMO system. The main issue solved in this paper is finding a suitable set of controllers for the considered non-linear system. The results show performance improvement of the system's performances (settling time, steady stare error, overshoot) after implementing the GA offline module.

In [13] is developed a method which allows the controller designers to perform optimal tuning of PID controller using an adaptive hybrid particle swarm optimization algorithm, namely AHPSO.

In the current paper a set of four performance indexes is analyzed, each with its own advantages and disadvantages. pentru selecţia unei noi generaţii. Cu cât este mai mic indicele de performanţă, cu atât mai mare este conformitatea unui individ (conformitate $=1$ //indice performanţă)) şi cu atât mai aproape este de soluţie. Indicele de performanţă al întregului algoritm este dat de conformitatea populaţiei optime sau, dacă este cazul, de conformitatea soluţiei.

În această lucrare se testează trei funcţii de selecţie diferite pentru populaţia evaluată. Selecţia generează o roată de ruletă în care fiecare individ este reprezentat proporţional în funcţie de conformitatea acestuia. Cu cât este mai mare valoarea conformităţii, cu atât mai mult spaţiu va avea pe roată. Seleç̧ia are loc prin generarea unui număr aleator şi numărarea secţiunilor roţii. Indivizii cu conformitate mai mare au mai multe şanse de a fi selectaţi, deoarece li se atribuie o secţiune mai mare de roată. Funcţia de selecţie utilizează o listă a populaţiei sortate pe baza conformităţii, din care sunt eliminate extremele. Populaţia rezultată va avea apoi şanse mai mari să fie selectată. Metoda are o convergenţă mai lentă decât selecţia de tip roată de ruletă. Procedura de selecţie de tip competiţie implică efectuarea mai multor competiţii între un număr de indivizi aleşi la întâmplare din populaţia evaluată. Câştigătorul fiecărei competiţii este considerat a fi cel cu o valoare optimă a conformităţii şi, prin urmare, este selectat pentru recombinare.

\section{Evaluarea performanţei}

Prin tehnica optimizării evolutivă cu GA, parametrii regulatoarelor PID alese sunt reglaţi într-un mediu simulat.

În [12] se prezintă un algoritm genetic de control al unui sistem neliniar MIMO. Principala problemă rezolvată în această lucrare este găsirea unui set de regulatoare adecvate pentru sistemul neliniar luat în considerare. Rezultatele arată îmbunătăţirea performanţei sistemului (timp tranzitoriu, eroare staţionară, suprareglaj) după implementarea modululuiGA offline.

În [13] se dezvoltă o metodă care le permite proiectanţilor să ajusteze optim regulatorul PID utilizând un algoritm de optimizare hibrid adaptiv cu roiuri de particule (AHPSO).

În această lucrare se analizează un set de patru indici de performanţă, fiecare cu propriile avantaje şi dezavantaje. 
$l_{1}$ : the ISE (Integral Square Error) performance index is a general error minimizing index, making use of the quadratic error values obtained at a step response simulation:
$I_{1}$ : indicele de performanţă ISE (eroarea pătratică integrală) este un indice general de reducere la minimum, care utilizează valorile erorilor pătratice obţinute la simularea unui răspuns într-o etapă:

$$
I_{1}=\int_{0}^{\infty} \varepsilon^{2}(t) d t
$$

By using this performance index the penalization of positive and negative error values is achieved. ISE performance index is not very sensitive to parameter variations.

$I_{2}$ : the IAE (Integral Absolute Error) performance index is a general error minimizing index, making use of the absolute error values:

Utilizând acest indice de performanţă se realizează penalizarea valorilor de eroare pozitive şi negative. Indicele de performanţă ISE nu este foarte sensibil la variaţiile parametrilor.

$I_{2}$ : indicele de performanţă IAE (eroarea absolută integrală) este un indice general de reducere la minimum, care utilizează valori de eroare absolute:

$$
I_{2}=\int_{0}^{\infty}|\varepsilon(t)| d t .
$$

IAE performance index has a better sensitivity than ISE. Also, this performance index requires fewer processor operations, as instead of computing the square of error, only a removal of the sign is performed in order to obtain the absolute values.

$I_{3}$ : the ITAE (Integral of Time multiplied by the Absolute value of Error) is a very useful performance index, which penalizes long-term responses:

Indicele de performanţă IAE are o sensibilitate mai bună decât ISE. De asemenea, acest indice de performanţă necesită mai multe operaţii de procesare, deoarece în loc să calculeze pătratul erorii, se realizează doar o înlăturare a semnului pentru a obţine valorile absolute.

$I_{3}$ : ITAE (integrala timpului înmulţită cu valoarea absolută a erorii) este un indice de performanţă foarte util, care penalizează răspunsurile pe termen lung:

$$
I_{3}=\int_{0}^{\infty} t|\varepsilon(t)| d t
$$

This performance index is more selective than ISE and IAE. ITAE performance index generally produces oscillations and overshoots lower than IAE and ISE. ITAE uses time values, which, for numeric systems, are subjected to processor clock communication delays.

$I_{4}$ : the IEC (Integral of Error and Command) performance index makes use of the command values:
Acest indice de performanţă este mai selectiv decât ISE şi IAE. Indicele de performanţă ITAE produce în general oscilaţii şi suprareglări mai mici decât IAE şi ISE. ITAE utilizează valori de timp, care, în cazul sistemelor numerice, sunt supuse întârzierilor de comunicare între procesor şi ceas.

$I_{4}$ : indicele de performanţă IEC (integrala eroare şi comandă) utilizează valorile de comandă:

$$
I_{4}=\int_{0}^{\infty}\left(\varepsilon^{2}(t)+\rho u^{2}(t)\right) d t,
$$

where $\rho$ is a strict positive command penalty factor.

By minimizing this performance index is provided, besides the desired evolution of the error, the desired transient response and a minimization of the command in accordance with actuator limitations. Also, IEC requires more computing capacity than the first three indexes and is subject to the choice of the penalty factor. unde $\rho$ este un factor de penalizare a comenzii strict pozitiv.

Prin reducere rezultă acest indice de performanţă, pe lângă evoluţia dorită a erorii, răspunsul tranzitoriu dorit şi o reducere la minimum a comenzii în conformitate cu limitările elementului de execuţie. De asemenea, IEC necesită o capacitate de calcul mai mare decât primii trei indici şi este supus alegerii factorului de penalizare. 


\section{CASE STUDY}

For this study the control of one parameter was considered, namely the $\mathrm{pH}$ value. This SISO (Single Input Single Output) system is non-linear and it can be approximated by the rational s-transfer function:

\section{STUDIU DE CAZ}

În acest studiu s-a luat în considerare controlul unui singur parametru, şi anume valoarea pH-ului. Acest sistem SISO (Single Input Single Output) este neliniar şi poate fi aproximat prin funcţia raţională de transfer s:

$$
H_{P}(s)=\frac{B(s)}{A(s)}=\frac{K_{P}}{T_{P} \cdot s+1}
$$

where $K_{p}$ is the gain, and $T_{p}$ represents the dynamics of the plant.

This case study presents the comparative results obtained using simulation setup. Making use of three different selection procedures, the proposed control architecture is tested. The performance criteria taken into account include settling time, overshoot and steady state error of the step response. Table 2 presents both simulation results for each of the cases considered in this paper.

For the manually tuned controller, whose simulated responses are presented in Figure 2, the following performances were obtained (Table 1): unde $K_{p}$ este factorul de amplificare, iar $T_{p}$ reprezintă constanta de timp a procesului.

Acest studiu de caz prezintă rezultatele comparative obţinute utilizând un proces de simulare. Arhitectura de control propusă este testată utilizând trei proceduri de selecţie diferite. Criteriile de performanţă luate în considerare includ timpul tranzitoriu, suprareglajul şi eroarea staţionară ale răspunsului sistemului la intrare de tip treaptă. Tabelul 2 prezintă rezultatele ambelor simulări pentru fiecare dintre cazurile analizate în lucrare.

Pentru regulatorul acordat manual, ale cărui răspunsuri simulate sunt prezentate în Figura 2, s-au obţinut următoarele performanţe (Tabelul 1):

Table 1: Simulation performances for the manually tuned controller

Tabelul 1: Performanţele de simulare ale regulatorului ajustat manual

\begin{tabular}{c|c|c|c}
\hline & $\begin{array}{c}\text { Settling Time (s) } \\
\text { Timp tranzitoriu (s) }\end{array}$ & $\begin{array}{c}\text { Overshoot (\%) } \\
\text { Suprareglaj (\%) }\end{array}$ & $\begin{array}{c}\text { Steady State Error (\%) } \\
\text { Eroare staţionară (\%) }\end{array}$ \\
\hline \hline ITP & 6.2 & 0 & 0 \\
\hline
\end{tabular}

Table 2: Simulation study analysis

Tabelul 2: Analiza studiului de simulare

\begin{tabular}{|c|c|c|c|c|c|c|c|c|c|}
\hline & \multicolumn{3}{|c|}{$\begin{array}{c}\text { Settling Time }(s) \\
\text { Timp tranzitoriu }(s)\end{array}$} & \multicolumn{4}{c|}{$\begin{array}{c}\text { Overshoot (\%) } \\
\text { Suprareglaj (\%) }\end{array}$} \\
\hline & $I_{1}$ & $I_{2}$ & $I_{3}$ & $I_{4}$ & $I_{1}$ & $I_{2}$ & $I_{3}$ & $I_{4}$ \\
\hline AG10G RSF & 3.0 & 4.0 & 4.2 & 3.2 & 0 & 0 & 0 & 0 \\
\hline AG20G RSF & 3.2 & 3.6 & 3.6 & 3.4 & 0 & 0 & 0 & 0 \\
\hline AG25G RSF & 3.8 & 4.2 & 3.4 & 4.0 & 0 & 0 & 0 & 0 \\
\hline AG50G RSF & 3.6 & 3.2 & 2.8 & 3.2 & 0 & 0 & 0 & 0 \\
\hline AG25G RWSF & 4.0 & 3.8 & 3.2 & 3.8 & 0 & 0 & 0 & 0 \\
\hline AG25G TSF & 3.6 & 3.2 & 3.6 & 3.8 & 0 & 0 & 0 & 0 \\
\hline
\end{tabular}

The cases analyzed in this paper are (Table 1, Table 2): ITP - the implicit tuning parameters are used; AG10G RSF - the tuning parameters are obtained by running a
Cazurile analizate în această lucrare sunt următoarele (Tabelul 1, Tabelul 2): ITP - s-au folosit parametrii de reglare impliciţi; AG10G RSF - parametrii de 
10 generation AG with ranking selection; AG20G RSF the tuning parameters are obtained by running a 20 generation AG with ranking selection; AG25G RSF - the tuning parameters are obtained by running a 25 generation AG with ranking selection; AG50G RSF - the tuning parameters are obtained by running a 50 generation AG with ranking selection; AG25G RWSF the tuning parameters are obtained by running a 25 generation AG with roulette wheel selection; AG25G TSF - the tuning parameters are obtained by running a 25 generation AG with tournament selection. For all the cases presented in Table 2, the steady state error was 0 .

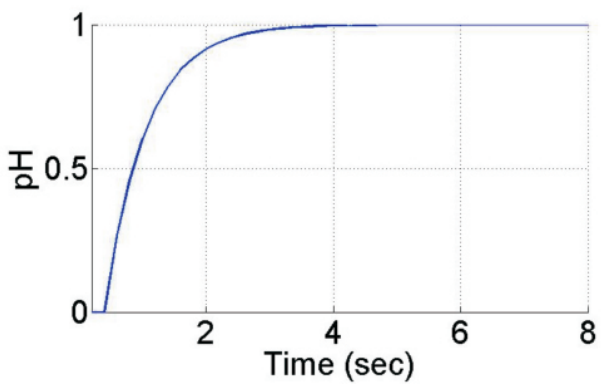

Figure 3. Simulated response of the best controller for the first performance index

Figura 3. Răspuns simulat al celui mai bun regulator pentru primul indice de performanţă

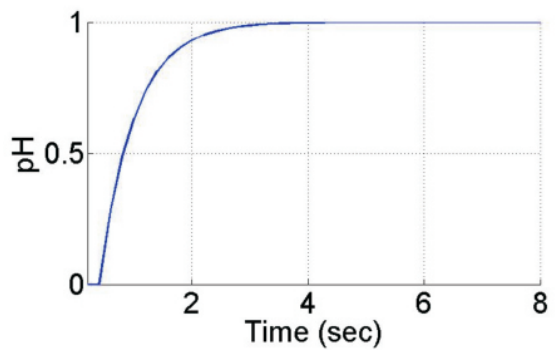

Figure 5. Simulated response of the best controller for the third performance index

Figura 5. Răspuns simulat al celui mai bun regulator pentru al treilea indice de performanţă

Figures 3, 4, 5, and 6 present the simulation responses for the best controllers out of all the analysed cases. Comparing these results with the implicit set of controllers found manually by a human operator (Figure 2), the decrease in settling time is significant for the system working with GA tuned controllers. reglare sunt obţinuţi utilizând un GA de generaţia a 10-a cu selecţie de tip clasament; AG20G RSF - parametrii de reglare sunt obţinuţi utilizând un GA de generaţia a 20-a cu selecţie de tip clasament; AG25G RSF - parametrii de reglare sunt obţinuţi utilizând un GA de generaţia a 25-a cu selecţie de tip clasament; AG50G RSF - parametrii de reglare sunt obţinuţi utilizând un GA de generaţia a 50-a cu selecţie de tip clasament; AG25G RWSF - parametrii de reglare sunt obţinuţi utilizând un GA de generaţia a 25-a cu selecţie de tip roată de ruletă; AG25G TSF - parametrii de reglare sunt obţinuţi utilizând un GA de generaţia a 25-a cu selecţie de tip competiţie. Pentru toate cazurile prezentate în Tabelul 2, eroarea staţionară a fost 0 .

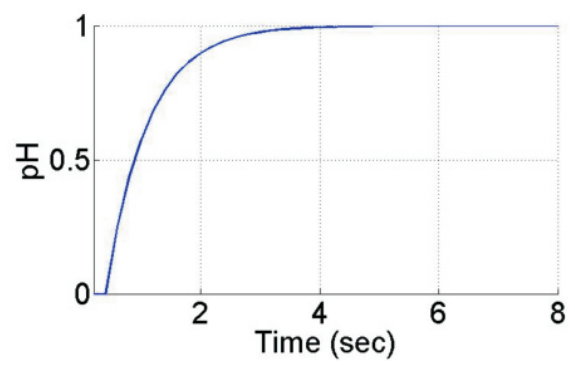

Figure 4. Simulated response of the best controller for the second performance index

Figura 4. Răspuns simulat al celui mai bun regulator pentru al doilea indice de performanţă

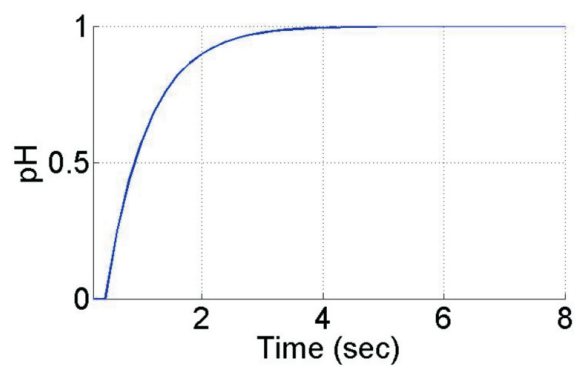

Figure 6. Simulated response of the best controller for the fourth performance index

Figura 6. Răspuns simulat al celui mai bun regulator pentru al patrulea indice de performanţă

Figurile 3, 4, 5 şi 6 prezintă răspunsurile simulate pentru cele mai bune regulatoare din toate cazurile analizate. Comparând aceste rezultate cu setul implicit de regulatoare găsit manual de un operator uman (Figura 2), scăderea timpului tranzitoriu este semnificativă pentru sistemul care utilizează regulatoare reglate cu GA. 


\section{CONCLUSIONS}

This paper presented a genetic algorithm based control strategy for non-linear MIMO systems. The main issue solved in this paper is finding suitable parameters of PID controllers for the considered system by providing different performance indexes to the genetic algorithms. The control strategy was applied to leather manufacturing process. Simulation results show improvement in the system's performances after implementing the GA offline module. This proves that the proposed control strategy is able to make the closed-loop system behave as expected according to different given performance indexes. A major issue in this paper was the initialization procedure of the genetic algorithms which can influence the outcome of the optimization performed.

By analyzing the simulation and experimental results, the proposed control strategy proved to be better that the one proposed by [13]. With the proposed control strategy were obtained better results in terms of overshoot, while there cannot be made a comparison in terms of settling time because in both studies were considered different plants having different dynamics. In the presented study more performance indexes like ITAE, IEC were considered, and again, the proposed control strategy proved its efficiency.

The authors consider of major importance the further study of the genetic algorithm control module which can be enhanced by real-time optimization implementation in a distributed fully-online control system.

\section{Acknowledgements}

This work was supported by the European Fund for Regional Development and the Romanian Government in the framework of Sectoral Operational Programme under the project INNOVA-LEATHER: «Innovative technologies for leather sector increasing technological competitiveness by RDI, quality of life and environmental protection" - contract POS CCE-AXIS 2-O 2.1.2 no. 242/20.09.2010 ID 638 COD SMIS-CSNR 12579.

\section{CONCLUZII}

Această lucrare prezintă o strategie de control bazată pe un algoritm genetic pentru sisteme neliniare MIMO. Principala problemă rezolvată în lucrare este găsirea unor parametri adecvaţi ai regulatoare PID pentru sistemul studiat prin stabilirea unor diferiţi indici de performanţă pentru algoritmii genetici. Strategia de control a fost aplicată procesului de fabricare a pielii. Rezultatele simulării arată o îmbunătăţire a performanţei sistemului după implementarea modulului GA offline. Acest lucru demonstrează că strategia de control propusă are capacitatea de a induce sistemului în buclă închisă un comportament dorit în funcţie de diferiţii indici de performanţă stabiliţi. O problemă majoră a fost procedura de iniţializare a algoritmilor genetici, care poate influenţa rezultatul optimizării efectuate.

Analizând rezultatele experimentale şi ale simulării, strategia de control propusă s-a dovedit a fi mai bună decât cea propusă în [13]. Cu strategia de control propusă s-au obţinut rezultate mai bune în ceea ce priveşte suprareglajul, dar nu se poate face o comparaţie în ceea ce priveşte timpul tranzitoriu deoarece în ambele studii s-au analizat diferite fabrici cu dinamici diferite. În acest studiu s-au luat în considerare mai mulţi indici de performanţă, precum ITAE, IEC, şi din nou, strategia de control propusă şi-a dovedit eficienţa.

Autorii consideră de mare importanţă continuarea studierii modulului de control cu algoritmi genetici care poate fi îmbunătăţit prin implementarea unei optimizări în timp real într-un sistem de control distribuit integral online.

\section{Mulţumiri}

Această lucrare a fost finanţată de Fondul European pentru Dezvoltare Regională şi Guvernul român, în cadrul Programului Operaţional Sectorial, în cadrul proiectului INNOVA LEATHER: «Tehnologii inovative pentru sectorul de pielărie care să asigure creşterea competitivităţii prin $\mathrm{CDI}$, calităţii vieţii şi protecţia mediului» - contract POS CCE-AXA 2-O 2.1.2 nr. 242/20.09.2010 ID 638 COD SMIS - CSNR 12579. 


\section{REFERENCES}

1. Dumitrache, I., Automatic Tuning Engineering, Volume 1 (in Romanian), Politehnica Press, Romania, 2010.

2. Dumitrache, I., Automatics, Volume 1 (in Romanian), Romanian Academy Press, Bucharest, Romania, 2010.

3. Iserman, R., Digital Control Systems, Volume I, Springer-Verlag Berlin Heidelberg, Germany, 1989.

4. Hanchevici, A.B., Guţă, S.A., Supervised Multi-Agent Control of Leather Manufacturing Process by Using the Fuzzy Logic, Revista de Pielarie Incaltaminte (Leather and Footwear Journal), 2012, 12, 2, 101-112.

5. Dobrowiecki, T., Schoukensb, J., Measuring a linear approximation to weakly nonlinear MIMO systems, Automatica, 2007, 43, 1737-1751.

6. Ge, S.S., Tee, K.P., Approximation-based control of nonlinear MIMO time-delay systems, Automatica, 2007, 43, 31-43.

7. Lin, J., Lian, R.-J., Hybrid fuzzy-logic and neural-network controller for MIMO systems, Mechatronics, 2009, 19, 972 986.

8. Zhoua, Y., Wu, Y., Output feedback control for MIMO nonlinear systems using factorization, Nonlinear Analysis, 2008, 68, 1362-1374.

9. Mizumoto, I., Chen, T., Ohdaira, S., Kumona, M., Iwaia, Z., Adaptive output feedback control of general MIMO systems using multirate sampling and its application to a cart-crane system, Automatica, 2007, 43, 2077-2085.

10. Shaocheng, T., Changying, L., Yongming, L., Fuzzy adaptive observer backstepping control for MIMO nonlinear systems, Fuzzy Set Syst, 2009, 160, 2755-2775.

11. Dumitrache, I., Buiu, C., Genetic Algorithms (in Romanian), Nemira, Cluj-Napoca, Romania, 1999.

12. Patrascu, M., Hanchevici, A.B., Dumitrache, I., Tuning of PID Controllers for Non-Linear MIMO Systems Using Genetic Algorithms, Proceedings of the 18th IFAC Congress, Milano, Italy, 2011, 12644-12649.

13. Markos, S., Kamal, H., Optimal Tuning of PID Controller using Adaptive Hybrid Particle Swarm Optimization Algorithm, Int J Comput Commun, 2012, VII, 1, 101-114.

Article received/Data primirii articolului: 31.08.2015

Accepted/Acceptat la data: 27.11.2015 